\title{
Microbial Analysis of Processed Foods Stored in Domestic Refrigerators of Selected Eateries in Ile-Ife, Osun State, Nigeria
}

\author{
Odewade Joseph Oluwaseun ${ }^{1, *}$, Oyelami Lydia Oluwatosin ${ }^{2}$, Fasogbon Albert Oluwasoga ${ }^{3}$ \\ ${ }^{1}$ Department of Microbiology, Faculty of Science, Federal University, Dutsin-Ma, Nigeria \\ ${ }^{2}$ Department of Environmental Management, Faculty of Earth and Environmental Sciences, Bayero University, Kano, Nigeria \\ ${ }^{3}$ Department of Microbiology, Faculty of Science, Bayero University, Kano, Nigeria
}

Email address:

odewadejoseph@yahoo.com (J. O. Odewade)

${ }^{*}$ Corresponding author

\section{To cite this article:}

Odewade Joseph Oluwaseun, Oyelami Lydia Oluwatosin, Fasogbon Albert Oluwasoga. Microbial Analysis of Processed Foods Stored in Domestic Refrigerators of Selected Eateries in Ile-Ife, Osun State, Nigeria. American Journal of Bioscience and Bioengineering. Vol. 6, No. 3, 2018, pp. 14-19. doi: 10.11648/j.bio.20180603.11

Received: October 29, 2018; Accepted: November 19, 2018; Published: December 28, 2018

\begin{abstract}
Consumption of contaminated refrigerated foods is increasing the incidence of food-borne diseases globally. However, there is paucity of data on prevalence of microbes associated with these foods from Osun State, Nigeria, thus, the need for isolation and characterization of microbes associated with refrigerated foods from this region. A total of 80 processed food samples were collected aseptically and refrigerated for four days. Samples were analyzed for the presence of bacteria and fungi while antibiotic resistance patterns of bacterial isolates were determined using standard methods. Mean bacterial count ranged from $7.0 \times 10^{4}$ to $3.7 \times 10^{5} \mathrm{cfu} / \mathrm{ml}$ with highest bacterial count of $3.7 \times 10^{5} \mathrm{cfu} / \mathrm{ml}$ obtained from melon soup sample, while least count of $7 \times 10^{4} \mathrm{cfu} / \mathrm{ml}$ was obtained from cooked meat. Fungal count ranged from $2.0 \times 10^{2}$ to $5.6 \times 10^{3} \mathrm{sfu} / \mathrm{ml}$ with cooked beans having the highest count of $5.6 \times 10^{3} \mathrm{sfu} / \mathrm{ml}$. The bacteria that were isolated from refrigerated processed food samples include Corynebacterium kutscheri (47.05\%), Bacillus spp (14.70\%), Staphylococcus aureus (11.76\%), Lactobacillus fermenti (5.8\%), Aeromonas hydrophila (5.8\%), Pseudomonas spp (5.88\%), Lactobacillus casei (2.94\%), Lactobacillus delbrueckii (2.94\%) and Citrobacter freundii (2.94\%), while fungi isolated were Aspergillus fumigatus (24.56\%), Aspergillus niger (21.05\%), Aspergillus flavus (14.04\%), Aspergillus brevipes (14.04\%), Mucor spp (7.02\%), Penicillium spp (8.77\%) and Saccharomyces spp (10.53\%). Corynebacterium kutscheri had the highest resistance of 17(37\%) while Lactobacillus casei showed no resistance $(0 \%)$ to the antibiotics used. This study showed high bacterial and fungal counts from the analyzed samples, hence, the need to ensure hygienic food processing and refrigerating conditions.
\end{abstract}

Keywords: Food-borne Diseases, Refrigerated Foods, Antibiotic Resistance, Food Processing

\section{Introduction}

Foods refrigerated can become vectors for food-borne illness by contamination with food-borne pathogens in retail stores, processing plants, or consumers' homes [1]. These spoilage-causing or pathogenic microorganisms are often able to grow at low temperatures and lead to reduction of shelf life or even affect consumer's health [2-3]. The perishable raw or cooked food that could serve as a growth medium must be stored to prevent the multiplication of bacteria that have survived during processing or handling [4]. Because most foodborne bacteria and molds that are agents of spoilage or infection can multiply at room temperature, manipulation of the holding temperature is a useful preservation method [4]. Different food requires different places and temperature for storage [5]. For instance, fresh meat, fish and poultry are stored in cold storage such as freezers, and in containers with crack ice just like what they do with the fish sold in the market [6]. Fruits and vegetables are placed in airy and cool places or in the vegetable compartment of the refrigerator [7]. Despite low 
temperatures, hygienic designs and cleaning recommendations, refrigerators can be hot spots for bacteria [8]. Staphylococcus, Pseudomonas, Bacillus, Enterobacteriaceae and Fungi are primarily found in household refrigerators [9-10]. Studies in Ireland have shown that the concentration of viable cells in refrigerators is around $\log _{10}{ }^{7.1} \mathrm{cfu} \mathrm{cm}^{-2}$ in average. In addition, more than half of the inspected refrigerators contained pathogenic microorganisms [10]. Psychrotolerant microorganisms are more widely distributed in nature than psychrophiles and can be isolated from soils and water in temperate climates, as well as from meat, milk and other dairy products, cider, vegetables, and fruit stored at refrigeration temperatures $\left(4^{\circ} \mathrm{C}\right)$. Psychrotropic pathogens include Yersinia enterocolitica, Listeria monocytogenes, non-proteolytic strains of Clostridium botulinum, some strains of enterotoxigenic Escherichia coli and Aeromonas hydrophila. The practice of storing food at refrigeration temperature is common for controlling the growth of psychrotrophic microorganisms, some pathogens, and maintaining product quality [11]. Nevertheless, fungi and psychrotrophic bacteria are commonly associated with spoilage of food at refrigerator temperatures. Fungi predominate in refrigerated food spoilage when low water activity, high acidity or packaging conditions selects for their growth over bacteria in foods. Psychrotrophic fungi are also commonly isolated from refrigerated fresh animal products, fruits and vegetables [12] and ready to eat foods [13]. The aim of this study is to isolate, characterize and determine the prevalence of microorganisms associated with refrigerated foods from selected eateries in Ile-Ife, Osun State, Nigeria.

\section{Materials and Methods}

\subsection{Collection of Samples}

A total of 80 samples which comprises of two samples per each of the freshly prepared processed foods which includes cooked rice, melon soup, cooked meat, cooked beans and liquid canned milk were collected aseptically from selected eateries in Obafemi Awolowo University, Ile-Ife, Osun State, Nigeria for 8 weeks between March and May, 2017. The food samples were allowed to cool before refrigerating for 4 days. Afterwards, refrigerated samples were collected aseptically and transported immediately to Microbiology Department laboratory at Obafemi Awolowo University, Ile-Ife, Osun State, Nigeria for microbial analysis.

\subsection{Enumeration and Isolation of Organisms}

A ten-fold serial dilution was carried out immediately and appropriate dilutions were used for microbial enumeration using standard pour plate method. The microbial load of samples were determined using Nutrient agar (NA) $\left(37^{\circ} \mathrm{C}\right.$ for 24-48 h) and Malt Extract agar (MEA) containing $0.05 \mathrm{~g} / \mathrm{L}$ streptomycin $\left(25^{\circ} \mathrm{C}\right.$ for 5 days) for total bacterial and fungal counts respectively. Isolation of Lactic Acid Bacteria was carried out using De Man, Rogosa and Sharpe (MRS) agar (Oxoid, UK) at $37^{\circ} \mathrm{C}$ for 24 to 72 hours in microaerophilic environment. Afterwards, observed colonies were counted and isolated from each refrigerated food samples cultured plates.

\subsection{Characterization of Bacterial Isolates}

The isolates were characterized based on morphological and biochemical analysis and was compared with standards using Bergey's manual.

\subsection{Characterization of Fungal Isolates}

The fungal isolates were identified based on their colonial morphology and microscopic examination. Characterization based on size, texture, pigmentation, shape and septation of hyphae were also made. The technique of James and Natalie [14] was adopted for identification of the unknown isolated fungi using lactophenol cotton blue stain. The identification was achieved by placing a drop of the stain on clean slide and a small portion of the mycelium from the fungal cultures was picked and placed on the stain. The mycelium was spread evenly on the slide with the inoculating needle. A cover slip was gently applied with little pressure to eliminate air bubbles and observed using $\times 10$ and $\times 40$ objective lens. The species encountered were identified using Pictorial atlas for identification of seed and soil fungi [15].

\subsection{Antibiotics Sensitivity Test}

The bacterial isolates were tested for their sensitivity to antibiotics by means of disc diffusion method as recommended by Clinical and Laboratory Standards Institute (CLSI). Sensitivity was carried out on Mueller Hinton Agar (MHA) prepared in accordance to the manufacturer's instructions and sterilized by autoclaving at $121^{\circ} \mathrm{C}$ for 15 minutes before dispensing into sterile Petri dishes. The plates were seeded with standardized inoculums $(0.5$ McFarland standard) by means of a sterile cotton swab which was used to introduce the organism on entire agar surface horizontally, vertically and around the edges of the plates. The disc was then aseptically applied to the surface of the agar plates with the aid of sterile forceps, incubated in an inverted position at $37^{\circ} \mathrm{C}$ for 24 hours. After incubation, each zone of inhibition was measured and interpreted by comparing with CLSI standards to determine their resistance patterns.

\section{Results}

\subsection{Bacterial and Fungal Enumeration}

Five refrigerated food samples were analyzed for the presence of bacteria and fungi with standard plate count method used for the analysis. The bacterial count ranged from $7 \times 10^{4}$ to $3.7 \times 10^{5} \mathrm{cfu} / \mathrm{ml}$ with highest bacterial colony count obtained from soup $\left(3.7 \times 10^{5} \mathrm{cfu} / \mathrm{ml}\right)$ while the least colony count of $7.0 \times 10^{4} \mathrm{cfu} / \mathrm{ml}$ gotten from analyzed meat sample. The fungal count ranged from $2.0 \times 10^{2}$ to $5.6 \times 10^{3}$ $\mathrm{sfu} / \mathrm{ml}$ with beans having the highest counts of $5.6 \times 10^{3}$ $\mathrm{sfu} / \mathrm{ml}$ as shown in table 1 . 
Table 1. Mean bacterial and fungal counts in refrigerated food samples.

\begin{tabular}{lll}
\hline Food samples & $\begin{array}{l}\text { Bacterial Counts } \\
(\mathbf{C f u} / \mathbf{m l})\end{array}$ & $\begin{array}{l}\text { Fungal Counts } \\
(\mathbf{S f u} / \mathbf{m l})\end{array}$ \\
\hline Cooked Rice & $2.6 \times 10^{5}$ & $3.0 \times 10^{3}$ \\
Cooked Beans & $1.8 \times 10^{5}$ & $5.6 \times 10^{3}$ \\
Cooked Meat & $7.0 \times 10^{4}$ & $3.5 \times 10^{3}$ \\
Melon Soup & $3.7 \times 10^{5}$ & $2.0 \times 10^{2}$ \\
Liquid canned milk & $1.1 \times 10^{5}$ & $4.7 \times 10^{3}$ \\
\hline
\end{tabular}

\subsection{Percentage Occurrence of Bacterial Isolates}

Table 2 shows the percentage occurrence of bacterial isolated from refrigerated food samples. Corynebacterium kutscheri was dominant organism with the percentage frequency of $47.05 \%$ followed by Bacillus spp with $14.70 \%$ while Lactobacillus casei, Lactobacillus delbrueckii and Citrobacter freundii had $2.94 \%$ respectively as presented on table 2 .

Table 2. Percentage occurrence of bacterial isolates.

\begin{tabular}{llll}
\hline S/NO & Bacteria & Frequency & \% Occurrence \\
\hline 1 & Corynebacterium kutscheri & 32 & $32(47.05)$ \\
2 & Bacillus spp & 10 & $10(14.70)$ \\
3 & Staphylococcus aureus & 8 & $8(11.76)$ \\
4 & Aeromonas hydrophila & 4 & $4(5.88)$ \\
5 & Pseudomonas spp & 4 & $4(5.88)$ \\
6 & Lactobacillus fermenti & 4 & $4(5.88)$ \\
7 & Lactobacillus casei & 2 & $2(2.94)$ \\
8 & Lactobacillus delbrueckii & 2 & $2(2.94)$ \\
9 & Citrobacter freundii & 2 & $2(2.94)$ \\
& & Total & 100 \\
\hline
\end{tabular}

\subsection{Percentage Occurrence of Fungal Isolates}

Table 3 shows the percentage frequency of fungi isolated from refrigerated food samples which consist of different species of fungi. The fungal isolates were identified as Aspergillus fumigatus, Aspergillus niger, Aspergillus flavus, Mucor spp, Penicillium spp and Saccharomyces spp. Aspergillus fumigatus (24.56\%) was the most predominant fungal isolate followed by Aspergillus niger (21.05\%). Mucor spp was the least fungal isolates with $7.02 \%$.
Table 3. Percentage occurrence of fungal isolates.

\begin{tabular}{llll}
\hline S/N & Fungi & Frequency & \% Occurrence \\
\hline 1 & Aspergillus fumigatus & 14 & $14(24.56)$ \\
2 & Aspergillus niger & 12 & $12(21.05)$ \\
3 & Aspergillus flavus & 8 & $8(14.04)$ \\
4 & Aspergillus brevipes & 8 & $8(14.04)$ \\
5 & Saccharomyces spp & 6 & $6(10.53)$ \\
6 & Penicillium spp & 5 & $5(8.77)$ \\
7 & Mucor spp & 4 & $4(7.02)$ \\
& & Total & 100 \\
\hline
\end{tabular}

\subsection{Percentage Resistance of Bacterial Isolates to Various Antibiotics}

Table 4 shows the percentage resistance of each bacterial isolates to different antibiotics used in this study. Out of 68 bacteria isolated from refrigerated food samples, 46 bacterial isolates were resistant to different antibiotics used in this study. Corynebacterium kutscheri had the highest resistance of $17(37 \%)$ while Lactobacillus casei showed no resistance $(0 \%)$ to the antibiotics used.

Table 4. Percentage resistance of bacterial isolates to various antibiotics.

\begin{tabular}{lll}
\hline Bacterial isolates & Frequency & Resistant (\%) \\
\hline Aeromonas hydrophila & 4 & $4(8.7)$ \\
Bacillus spp & 8 & $8(17.4)$ \\
Corynebacterium kutsceri & 17 & $17(37)$ \\
Citrobacter freundii & 2 & $2(4.3)$ \\
Lactobacillus delbrueckii & 2 & $2(4.3)$ \\
Lactobacillus fermenti & 4 & $4(8.7)$ \\
Pseudomonas spp & 4 & $4(8.7)$ \\
Staphylococcus aureus & 5 & $5(10.9)$ \\
Lactobacillus casei & - & $-(0 \%)$ \\
& Total & 100 \\
\hline
\end{tabular}

\subsection{Multiple Antibiotic Resistance Patterns of Isolates}

Table 5 shows the multiple antibiotic resistance pattern of bacterial isolates. The bacterial isolates were resistant to different classes of antibiotics. The highest antibiotic resistance pattern (APX, AM, CPX, CN, E, R, S, SXT) was observed in Corynebacterium kutscheri.

Table 5. Multiple antibiotic resistance patterns of bacterial isolates.

\begin{tabular}{|c|c|c|c|}
\hline Bacterial Isolates & Antibiotic Resistance Pattern & Frequency & Resistant (\%) \\
\hline Aeromonas hydrophila & $\mathrm{COX}, \mathrm{CRO}, \mathrm{N}, \mathrm{C}, \mathrm{SXT}, \mathrm{PX}$ & 4 & $4(12.1)$ \\
\hline Bacillus spp & APX, CPX, E, R, S, SXT, Z & 5 & $5(15.2)$ \\
\hline Citrobacter freundii & $\mathrm{COX}, \mathrm{N}, \mathrm{PX}, \mathrm{T}$ & 3 & $3(9.0)$ \\
\hline Corynebacterium kutscheri & APX, AM, CPX, CN, E, R, S, SXT & 6 & $6(18.2)$ \\
\hline Lactobacillus delbrueckii & APX, E, R, S & 4 & $4(12.1)$ \\
\hline Lactobacillus fermenti & $\mathrm{AM}, \mathrm{CN}, \mathrm{CPX}, \mathrm{S}, \mathrm{E}$ & 4 & $4(12.1)$ \\
\hline Pseudomonas spp & $\mathrm{COX}, \mathrm{C}, \mathrm{CN}, \mathrm{N}, \mathrm{PX}, \mathrm{T}$ & 5 & $5(15.2)$ \\
\hline & & Total & 100 \\
\hline
\end{tabular}

KEY

$\mathrm{COX} \rightarrow$ Cephalexin, $\mathrm{CRO} \rightarrow$ Ceftriaxone, $\mathrm{PX} \rightarrow$ Ampicillin, $\mathrm{CPX} \rightarrow$ Ciprofloxacin,

$\mathrm{N} \rightarrow$ Nitrofuratoin, $\mathrm{SXT} \rightarrow$ Cotrimoxazole, $\mathrm{T} \rightarrow$ Tetracycline, $\mathrm{C} \rightarrow$ Chloramphenicol,

$\mathrm{OFX} \rightarrow$ Ofloxacin, $\mathrm{CN} \rightarrow$ Gentamicin, $\mathrm{PEF} \rightarrow$ Pefloxacin, $\mathrm{APX} \rightarrow$ Ampiclox,

$\mathrm{R} \rightarrow$ Rocephin (Ceftriaxone), $\mathrm{E} \rightarrow$ Erythromycin, $\mathrm{Z} \rightarrow$ Cefuroxime, $\mathrm{S} \rightarrow$ Streptomycin, $\mathrm{AM} \rightarrow$ Amoxicillin 


\section{Discussion}

The high microbial load $\left(3.7 \times 10^{5} \mathrm{cfu} / \mathrm{ml}\right.$ and $5.6 \times 10^{3}$ $\mathrm{sfu} / \mathrm{ml})$ observed in the refrigerated processed food samples as shown in table 1 are likely to be caused by unhygienic conditions and temperature abuse of the domestic refrigerators used for this study. Since most microorganisms are likely destroyed by the high temperature used for cooking, the high microbial load is likely to be post cooking. According to Oluwafemi et al. [16], the pathogens found in domestic refrigerators could contaminate food directly or indirectly and pose a major health risk to consumers in terms of food poisoning. Even at proper storage temperatures, some spoilage-causing or pathogenic microorganisms grow at low temperatures and lead to reduction of shelf life or affect consumer's health $[2,17]$. The high fungal count $\left(5.6 \times 10^{3}\right.$ $\mathrm{sfu} / \mathrm{ml}$ ) detected in the refrigerated food samples as shown in table 1 may be due to the fact that fungi grow well in an environment that has adequate nutrients and moisture [18]. Mold growth on refrigerated foods depend on several factors such as temperature (being the most important one), time of storage, moisture content, and concentration of carbohydrates on food source etc. Psychrotrophic bacteria and fungi are commonly associated with spoilage of food at refrigerator temperatures [19]. Low water activity, high acidity or packaging conditions selects for the growth of fungi over bacteria in refrigerated food spoilage. Mold genera that have psychrotropic species include Alternaria, Aspergillus, Botrytis, Cladosporium, Fusarium, Geothricum, Monascus, Mucor, Penicillium, Rhizopus, and Trichothecium. Among the yeast genera involved are Candida, Debaryomyces, Saccharomyces and Torulopsis [20].

Food kept for too long or that has been left out in humid conditions provides a good substrate for fungal growth [5]. Some fungi are cold tolerant and can even grow on old food in a refrigerator [5]. Some foods with high sugar or salt concentration will be difficult for most fungi to colonize, but most kinds of breads, fruits and vegetables are ideal [5]. The following organisms were isolated in descending order, Corynebacterium kutscheri (47.05\%), Bacillus spp (14.70\%), Staphylococcus aureus (11.76\%), Lactobacillus fermenti (5.13\%), Aeromonas hydrophila (5.13\%), Pseudomonas spp (5.13\%), Lactobacillus casei (2.56\%), Lactobacillus delbrueckii (2.56\%) and Citrobacter freundii $(2.56 \%)$ as shown in table 2. Several researchers have reported the frequency of Pseudomonas spp, Lactobacillus delbrueckii, Bacillus cereus, Aeromonas spp, Citrobacter spp, and Staphylococcus aureus in domestic refrigerators [19, 21, 22, 23]. The percentage occurrence of Staphylococcus aureus recovered in this study was $11.76 \%$. This result is higher than some previous reported detection, for example, 5.5\% [24], but lower than the $20 \%$ reported by Ojima et al. [10], or the $27.3 \%$ reported by Otu-Bassey et al. [25]. Staphylococcus aureus, as a common inhabitant (up to 50\%) of the human nose, throat, and skin [26] is perhaps more likely to contaminate foods stored inside domestic refrigerators by direct or indirect human contact during domestic food handling and storage. Many domestic refrigerators are incorrectly adjusted, operating above the recommended temperature and are therefore capable of supporting suboptimum but significant growth of mesophilic organisms such as Staphylococcus aureus, Escherichia coli and Salmonella spp [27].

Pseudomonas are aerobic, Gram-negative soil bacteria, some of which can degrade a wide variety of unusual compounds [28]. They generally require a high water activity for growth ( 0.95 or higher) and are inhibited by $\mathrm{pH}$ values less than 5.4 [28]. Some species grow at refrigeration temperatures (psychrophilic) while other are adapted for growth at warmer, ambient temperatures. Pseudomonas spp was isolated from the refrigerated food samples and this was consistent with Doyle, [28] which stated that some strains are adapted for growth at cold temperatures and spoil the foods in the refrigerator. Rawat, [29] also stated that some species of Pseudomonas can attack refrigerated and processed foods. Salmonella spp, Campylobacter spp and Escherichia coli were not detected in any of the refrigerated processed food samples. This was in agreement with Spiers et al. [30] who reported failure to detect these pathogens, not only in refrigerators but in a wide range of sites examined in domestic kitchens. Citrobacter freundii, the least bacterial isolated from refrigerated processed food samples was also reported by Osborne et al. [23].

Aspergillus fumigatus, Aspergillus niger, Aspergillus flavus, Aspergllus brevipes, Saccharomyces spp, Penicillium spp and Mucor spp were recovered from the refrigerated processed food samples. This was consistent with the work of Altunatmaz et al. [19] who reported the isolation of Aspergillus flavus, Aspergillus niger, Mucor spp, Penicillium spp and yeast in different types of ready-to-eat (RTE) foods stored in refrigerators. Pitt and Hocking, [31] also reported that different mold species have different optimal growth temperatures, with some able to grow in refrigerators.

Aspergillus fumigatus, Aspergillus niger, Aspergillus flavus, Aspergillus brevipes were the species of Aspergillus genera isolated from refrigerated food samples and these can be a possible source of aspergillosis transmission among consumer of the refrigerated foods. Aspergillus and related molds generally grow faster and are more resistant to high temperatures and low water activity than Penicillium spp and tend to dominate spoilage in warmer climates [28]. Mucor spp $(6.06 \%)$, the least fungi isolated was also reported in ready to eat foods stored in the refrigerator [19].

Out of the nine (9) bacterial genera isolated from refrigerated food samples, eight (8) were resistant (Aeromonas hydrophila, Bacillus spp, Corynebacterium kutscheri, Citrobacter freundii, Lactobacillus delbrueckii, Lactobacillus fermenti, Pseudomonas spp, Staphylococcus aureus) to different antibiotics used in this study while one (1) was susceptible (Lactobacillus casei) as shown in table 4. Also, high antibiotics resistance profile by Corynebacterium kutscheri 17(37\%) was observed followed by Bacillus spp 
$8(17.4 \%)$. As shown in table 5, the bacterial isolates were resistant to more than one class of antibiotics. This was in agreement with the findings of Lowy, [32]. Out of all the bacterial isolates recovered from the refrigerated processed food samples, Corynebacterium kutscheri had the highest antibiotics resistant (APX, AM, CPX, CN, E, R, S and SXT) pattern. This was consistent with the work of Olender, [33] who reported the resistance of Corynebacterium spp to different classes of antibiotics such as macrolides, lincosamides, fluoroquinolones, tetracyclines, beta-lactam and glycopeptides. Previously, multiple resistance to antibiotics by microorganisms were found mostly in hospitals where antimicrobial agents are used most frequently but resistance is found in refrigerated processed food materials as observed in this study. The clinical management of a number of food-borne infections have been complicated by antimicrobial resistant bacteria [34].

\section{Conclusion}

This study has shown that the pathogenic bacteria and fungi can survive in refrigerated food samples due to the high bacterial and fungal counts observed on the food samples and could therefore pose a consumer health risk. Refrigerated foods can become vectors for food-borne pathogens through temperature abuse and inadequate cleaning of the domestic refrigerators. It is crucial that the public be made aware that the refrigerator can represent a significant niche for the persistence and dissemination of food borne pathogens due to their reliance on refrigeration as a means of food preservation. Care must be taken in the consumption of refrigerated foods most especially after a long period of time. This study also suggests the need for surveillance and public health practitioners centre to intensify their effort in monitoring the refrigerated and processed food materials so as to prevent the emergence of antibiotic resistance by microorganisms.

\section{References}

[1] Kosa, K. M., Cates, C. S., Karnes, S., Godwin, S. L., and Chambers, D. (2007). Consumer home refrigeration practices: Results of a web-based survey. Journal of Food Protection, 70: 1640-1649.

[2] Krämer, J. (2002). Lebensmittel mikrobiologie. 4. Auflage. Stuttgart: Eugen Ulmer Verlag.

[3] Kreyenschmidt, J. (2003). Modellierung des Frischeverlustes vonFleischso wiedes EntfärbungsprozessesvonTemperaturZeitIntegratorenzur. Festlegung. AnforderungsrofilnfürdieproduktbegleitendeTemperaturuberwa chung. Bergen.

[4] Talaro, K. P., and Chess, B. (2012). Foundations in Microbiology. 8th edition, McGraw-Hill Companies, pp. 816818.

[5] Mitchell, D., Finkelhor, W., and Rickert, G. (2004). Refrigeration and food safety, In: How to store vegetables you've grown, pp. 345-404.

[6] Arora, R. C. (2003). Mechanical Vapour Compression Refrigeration. In: Refrigeration and air conditioning. New Delhi, India, pp. 1096.

[7] Prescott, L. M., Harley, P. J., and Klein, A. D. (2005). Microbiology. 6th edition, McGraw Hill Publishers, New York.

[8] Bielecki, J. (2003). Emerging food pathogens and bacterial toxins. Acta Microbiologica Polonica, 52: 17- 22.

[9] Ojima, M., Toshima, Y., Koya, E., Ara, k., Tokuda, H., Kawai, S., Kasuga, F., and Ueda, N. (2002). Hygiene measures considering actual distributions of microorganisms in Japanese households. Journal of Applied Microbiology, 93: 800-809.

[10] Kennedy, J., Jackson, V., Blair, I. S., McDowell, D. A. C., and Bolten, D. J. (2005). Food Safety knowledge of consumers and the microbial and temperature status of their refrigerators. Journal of Food Protection. 68: 1421-1430.

[11] Pal, A., Labuza, T. P., and Diez-Gonzalez, F. (2008). Shelf life evaluation for ready to eat slice uncured turkey breast and cured ham under probable storage conditions based on Listeria monocytogenes and psychrotroph growth. International Journal of Food Microbiology, 126: 49- 56.

[12] APHA (American Public Health Association). (2001). Compendium of methods for the microbiological examination of foods. American Public Health Association, Washington DC, USA.

[13] Alexopoulos, C. J., Mims, W. C., and Blackwell, M. (1996). Introductory Mycology, 4th edition. John Wiley and Sons, Inc., New York.

[14] James, G. C., and Natalie, S. (2011). Microbiology: A laboratory manual, 9th edition, San Francisco: Benjamin/Cummings Publishing Company, pp. 211-223.

[15] Watanabe, T. (2002). Pictorial atlas for identification of soil and seed fungi. Morphologies of cultured fungi and key to species. 2nd edition, CRC press. Boca Raton, London.

[16] Oluwafemi, F., Akpoguma, S., Oladiran, T., and Kolapo, A. (2015). Microbiological Quality of Household Refrigerators in Three Cities South-West of Nigeria. Journal of Microbial and Biochemical Technology, 7: 206-209. doi:10.4172/19485948.1000206.

[17] Ugur, M., Nazli, B., and Bostan, K. (2001). Food Hygiene. Tecknik publishing, Istanbul, Turkey.

[18] Dedesko, S., and Siegel, J. A. (2015). Moisture parameters and fungal communities associated with gypsum drywall in buildings. Microbiome, 3: 71.

[19] Altunatmaz, S. S., Issa, G., and Aydin, A. (2012). Detection of airborne Psychrotrophic bacteria and fungi in food storage refrigerators. Brazilian Journal of Microbiology, 1436-1443.

[20] Jay, J. M. (2000). Food Preservation and Some properties of Psychrotrophs, Thermophiles, and Radiation-Resistant Bacteria: In Modern Food Microbiology, 6th edition, Aspen Publishers Inc, Gaithersburg, Maryland. pp. 251-367.

[21] Bharathirajam, R., Gopinathan, R., and Prakash, M. (2012). Microbial management of household cold storage exploratory study in Jeddah, Saudi Arabia. International Journal of Current Microbiology and Applied Sciences, 1(1): 50-55. 
[22] Kampmann, Y., DE Clerk, E., Kohn, S., Patchala, D. K., Langerock, R., and Kreyenschmidt, J. (2008). Study on the antimicrobial effect of silver- containing inner liners in refrigerators. Journal of Applied Microbiology, 104: 18081814.

[23] Osborne, J. W., Rish, B. A., and Kumar Rohini, M. (2012). Isolation of various bacterial pathogens from domestic refrigerators. Asian Journal of Pharmaceutical and Clinical Research, 5(3): 0974-2441.

[24] Esfarjani, F., Khaksar, R., Nasrabadi, F. M., Roustaee, R., Alikharian, H., Khalaji, N., Khaneghah, A. M. and Hosseini, H. (2016). "A preventive approach to promote food safety: Bacterial contamination of domestic refrigerators". Food Journal, 118(8): 2076-2091. https://doi.org/10.1108/BFJ-012016-0025.

[25] Otu-Bassey, I., Ewaoche, I. S., Okon, B. F., and Ibor, U. A. (2017). Microbial Contamination of Household Refrigerators in Calabar Metropolis-Nigeria. American Journal of Epidemiology and Infectious disease. 5(1): 1-7. doi:10.12691/ajeid-5-1-1.

[26] Arbuthnott, J. P. (1990). Staphylococcal toxins in human disease. Journal of Applied Bacteriology (Supplement), 19: 101-107.

[27] Flynn, O. M. J., Blair, I., and McDowell, D. (2006). The efficiency and consumer operation of domestic refrigerators. International Journal of Refrigeration, 15: 307- 312.
[28] Doyle, E. M. (2007). FRI BRIEFINGS: Microbial Food Spoilage: Losses and Control Strategies. A Brief Review of the Literature. Food Research Institute, University of Wisconsin, Madison.

[29] Rawat, S. (2015). Food spoilage: Microorganisms and their prevention. Asian Journal of Plant Science and Research, 5(4): 47: 56.

[30] Spiers, J. P., Anderton, A., and Anderson, J. G. (1995.) A study of the microbial content of the domestic kitchen. International Journal of Environmental Health Research, 5: 109-122.

[31] Pitt, J. I. and Hocking, A. D. (2009). Fungi and Food Spoilage. 3rd edition, Heidelberg, Springer.

[32] Lowy, F. D. (2003). Antimicrobial resistance: The example of Staphylococcus aureus. Journal of Clinical Investigation, 119(9): 1265-1273.

[33] Olender, A. (2012). Mechanism of Antibiotic Resistance in Corynebacterium spp causing Infections in People, Antibiotic Resistant Bacteria-A Continuous Challenge in the Millennium, Dr Marina Pana (Ed.). ISBN: 978-51-0472-8.

[34] Mangel, A. R., Johnson, J. R., Foxman, F., O' Bryan, T. T., Fullerton, K. E. and Riley, W. L. (2001). Widespread distribution of urinary tract infections caused by a multidrug resistant Escherichia coli clonal group. The New England Journal of Medicine, 345: 1007- 1013. 